\title{
Common mental disorders in nursing students of the professionalizing cycle
}

\author{
Transtornos mentais comuns em acadêmicos de enfermagem do ciclo profissionalizante \\ Trastornos mentales comunes en académicos de enfermería del ciclo profesional
}

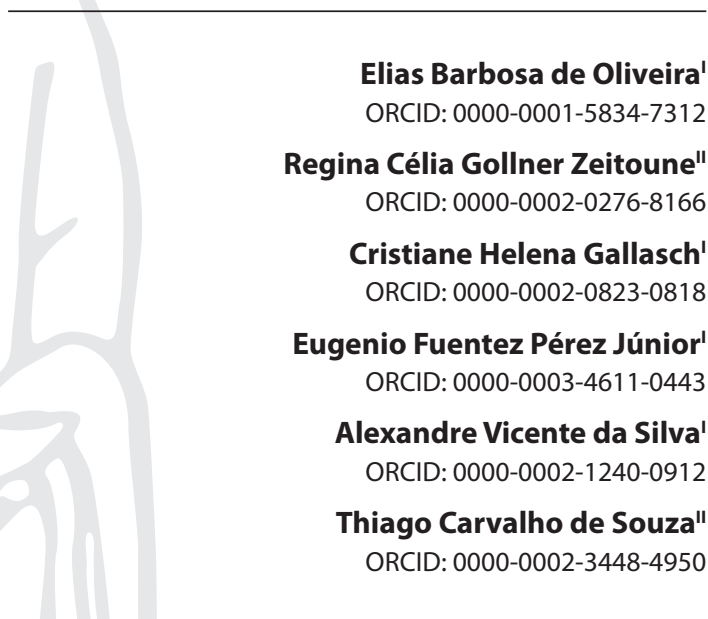

'Universidade do Estado do Rio de Janeiro. Rio de Janeiro, Rio de Janeiro, Brazil.

"Universidade Federal do Rio de Janeiro. Rio de Janeiro, Rio de Janeiro, Brazil.

How to cite this article: Oliveira EB, Zeitoune RCG, Gallasch CH, Pérez Jr EF, Silva AV, Souza TC. Common mental disorders in nursing students of the professionalizing cycle. Rev Bras Enferm. 2020;73(1):e20180154. doi: http://dx.doi.org/10.1590/0034-7167-2018-0154

Corresponding Author:

Elias Barbosa de Oliveira

E-mail: eliasbo@oi.com.br

EDITOR IN CHIEF: Dulce Aparecida Barbosa ASSOCIATE EDITOR: Marcos Brandão

\section{ABSTRACT}

Objectives: to verify the suspicion of common mental disorders in nursing students of the professionalizing cycle and the association with sociodemographic features. Method: crosssectional study with a sample of 85 students from a public university in the state of Rio de Janeiro (RJ) who responded to the Self-Report Questionnaire-20 and sociodemographic questions. Results: the suspicion prevalence of common mental disorders (CMD) in the sample was $55.3 \%$ and it was identified the association with the consumption of alcohol. Of the most frequent SRQ-20 complaints, 95.3\% reported "feeling nervous, tense or worried", $72.9 \%$ "having difficulty making decisions", 60\% "sleeping poorly" and 37.6\% "having lost interest by things ". Conclusion: high prevalence of CMD in the sample and the association with the consumption of alcohol requires preventive and therapeutic actions among the students that minimize the possibility of severe mental disorders related to the consumption of alcohol and other drugs.

Descriptors: Nursing; Students; Mental Disorders; Mental Health; Prevention.

\section{RESUMO}

Objetivos: verificar a suspeição de transtornos mentais comuns em acadêmicos de enfermagem no ciclo profissionalizante e a associação com as características sociodemográficas. Método: estudo transversal com uma amostra de 85 acadêmicos de uma universidade pública do estado do Rio de Janeiro (R) que responderam ao Self Report Questtionaire-20 e questões sociodemográficas. Resultados: a prevalência de suspeição de transtornos mentais comuns (TMC) na amostra foi de $55,3 \%$, sendo identificada a associação com o consumo de bebidas alcoólicas. Das queixas do SRQ-20 mais frequentes $95,3 \%$ afirmaram "se sentir nervosos, tenso ou preocupado", 72,9\% "ter dificuldades em tomar decisões", 60\% "dormir mal" e 37,6"ter perdido o interesse pelas coisas". Conclusão: a alta prevalência de TMC na amostra e a associação com o consumo de bebidas alcóolicas exige ações de cunho preventivo e terapêutico junto aos acadêmicos que, minimizem a possibilidade de transtornos mentais severos relacionados ao consumo de álcool e outras drogas.

Descritores: Enfermagem; Estudantes; Transtornos Mentais; Saúde Mental; Prevenção.

\section{RESUMEN}

Objetivos: verificar la sospecha de trastornos mentales comunes en académicos de enfermería en el ciclo profesional y la asociación con las características sociodemográficas. Método: estudio transversal con una muestra de 85 académicos de una universidad pública del estado de Río de Janeiro (RJ) que respondieron al Self-Report Questionnaire-20 y cuestiones sociodemográficas. Resultados: la prevalencia de sospecha de trastornos mentales comunes (TMC) en la muestra fue del $55,3 \%$, siendo identificada la asociación con el consumo de bebidas alcohólicas. De las quejas del SRQ-20 más frecuentes el 95,3\% afirmó"sentirse nervioso, tenso o preocupado", el 72,9\%"tiene dificultad en tomar decisiones", el 60\% "duerme mal" y el 37,6\% "perdió el interés por las cosas". Conclusión: la alta prevalencia de TMC en la muestra y la asociación con el consumo de bebidas alcohólicas requiere acciones de carácter preventivo y terapéutico junto a los académicos, para minimizar la posibilidad de trastornos mentales severos relacionados con el consumo de drogas. Descriptores: Enfermería; Estudiantes; Trastornos Mentales; Salud Mental; Prevención. 


\section{INTRODUCTION}

National and international studies among university students prove that since entering educational institutions, students are faced with an environment permeated by rules and obligations very different from high school. So stress is intensified due to the need to socialize with new colleagues and professors, the rules and the learning contents that require greater autonomy and responsibility. In addition, the demands arising from the conclusion of the course and the expectations regarding the professional future and insertion in the job market. In the health area, suffering is intensified due to the stages and other activities that put the student in the face of illness, death, and the suffering of patients and their families ${ }^{(1)}$.

In Nursing, the activities of the professional cycle are characterized as professional practice for giving the opportunity to exchange experiences and learning, contributing to the acquisition of knowledge and development of technical and relational skills. It enables the student's interaction with health institutions, professionals, patients and their families, which knowledge favors the insertion of the future professional in the health system. However, apprehending the competencies and skills of care, relationship and management, is a great challenge for undergraduates for being young, untrained and with no acquired adaptive mechanisms in the face of occupational stressors ${ }^{(2)}$.

At this stage of education, although the students work in health institutions under the supervision of the professor, they interact daily with several organizational problems such as high exigency and low control in face of the psychosocial risks involved. These include: high working hours, critical and life-threatening patients care, low decision-making power and inexperience to cope with unpredictable situations. Such risks cause changes in sleep patterns, fatigue, anxiety, unpleasant sensations in the stomach and headache, showing signs and symptoms that are predictors of common mental disorders (CMD) ${ }^{(3)}$.

A study about the suspicion of CMD in nursing students who sought to verify the association of these disorders with alcohol and tobacco consumption proved that, $46.1 \%$ of the sample have prevalent signs and symptoms of anxious depressive mood, somatization and decrease of vital energy; and the association with the consumption of these substances is not established. These data are relevant because they help to prevent the development of a psychopathological clinical picture, also enabling the implementation of preventive institutional programs for the consumption of alcohol and other drugs in the group ${ }^{(4)}$.

The CMD concept developed in the 70's through research on mental illness in primary health care and refers to a set of symptoms such as: insomnia, fatigue, irritability, forgetfulness, concentration difficulty, somatic complaints and others. These disorders may be associated with decreased of ability to work and to the sickness absenteeism; and it is a major public health problem ${ }^{(5)}$.

International studies prove the prevalence of CMD between $24.6 \%$ and $45.3 \%$ in the general population, being that in the samples of Brazilian municipalities the rates range from 17 to $35 \%{ }^{(6)}$. Although CMDs do not constitute a specific clinical body described in nosological manuals, they constitute a dimension of these psychopathological phenomena expressed at the collective level and result from genetic, behavioral and environmental determinants that are associated with factors such as gender, age group, marital status, living conditions and work ${ }^{(7-8)}$.

According to the World Health Organization (WHO), there is a high percentage of CMD in professionals from different areas, including health area, as a consequence of new production processes. Therefore, it is relevant to investigate the suspicion of CMD in Nursing because it is a category whose work features are based on interdependent actions of other professionals and users of the services; and usually developed under high pressure due to the several requirements of assistance and management ${ }^{(9)}$.

Aiming to fund the study on CMD in Nursing, it was carried out a survey of the state of the art in the Virtual Health Library (VHL), integrated with the Brazilian Nursing Database (BDENF), Latin American and Caribbean Health Sciences Literature (LILACS) Medical Literature Analysis and Retrieval System Online (MEDLINE) and Cumulative Index to Nursing and Allied Health Literature (CINAHL). It was selected articles published mainly in the country and between 2013 to 2017, being observed the incipience of research involving nursing workers and students.

\section{OBJECTIVE}

To verify the suspicion of common mental disorders in nursing students of the professionalizing cycle and the association with sociodemographic features.

\section{METHOD}

\section{Ethical aspects}

The study met ethical standards in research involving human being, and was approved by the Research Ethics Committee of the Hospital Universitário Pedro Ernesto (CEP/HUPE). After the invitation, the explanations about the research and scheduling, the data were collected in groups of a maximum of eight students in the own institution, in a private place, after signing the Informed Consent (IC). Although the collection was done in groups, the instruments were filled individually, and there was no discussion about the response options before, during and after completion. It was ensured anonymity and corroborated that participants could withdraw consent at any stage. It was clarified the importance of the student participation, considering the incipience of studies of this nature and the benefits in terms of institutional support to those with a suspicion of CMD.

\section{Design, study location and period}

Cross-sectional study with a quantitative approach carried out at a public university located in the city of Rio de Janeiro from March to December of 2016.

\section{Population and sample: inclusion criteria}

Of the 92 students enrolled and regularly attending the professionalizing cycle of the course, the sample for convenience was composed of 85 subtends of the professionalizing cycle. The losses occurred due to the absence at the time of collection, and there were no denials. We adopted as inclusion criteria those who were 
regularly enrolled and attending the last two periods and who were performing theoretical and practical activities in the hospital.

\section{Study variables}

The study included the following variables: gender; age; marital status; employment relationship; if the students lived with their parents; medical leave in the last twelve months; consumption of medicine, alcohol and tobacco; practice of physical activity; hours of sleep; and common mental disorders, according to the Self-Report Questionnaire 20 (SRQ-20).

\section{Study protocol}

The suspicion of CMD was verified by the SRQ-20 validated for the Brazilian context ${ }^{(10)}$ in 1986 and later in $2008^{(11)}$. It is a psychiatric screening instrument originally composed of 30 questions, being the Brazilian version consisted of 20 items for the screening of non-psychotic mental disorders with alternatives of dichotomous answers like"yes" or "no". The score is obtained by counting the affirmative answers, ranging from zero, which indicates a minimum probability of CMD, to 20, which corresponds to the maximum probability. The cut-off point used for the suspicion of CMD was at least eight positive answers for females and six for males due to gender issues and cultural context. It is a tool for tracking psychic suffering, and for the diagnosis, the standardized psychiatric interview must be performed ${ }^{(5,11)}$.

For the analysis of the data, it was used the program Statistical Package for the Social Science (SPSS ${ }^{\circledR}$ ) version 9.0 for Windows and was adopted the significance level of $5 \%$ was adopted, determining the suspicion of CMD and the association with sociodemographic variables by means of logistic regression using the Chi-SquarePearson test and Fisher's exact test. In the individual analysis were added the affirmative answers of the items that composed the factors related to the suspicion of CMD in order to obtain the score of each participant. In the group analysis, it was observed the number of affirmative answers for each factor in order to discuss the prevalence of signs and symptoms by factor in the sample. The results were discussed according to the studies that address CMD among nursing and medical students, residents of the health area, nursing workers and correlates to worker's health.

\section{RESULTS}

\section{Characteristics of the studies' participants}

Table 1 presents data regarding the sociodemographic characteristics of the sample and the association with the suspicion of CMD.

The study was composed by the total of students of the professionalizing cycle number $(n=92)$ and the sample had 85 (92.3\%) participants based on the established inclusion criteria, whose characteristics showed that it was a young group, mostly female, unmarried, who do not work or live with their parents.

On the state of health and other life habits, it was identified that a part of the students moved away from the training to address some health problem, uses medicines regularly, sleeps less than 8 hours a day, consumes alcohol eventually and practices some physical activity. According to the cutoff points established for the male and female sex, the overall suspicion of CMD in the sample was $55.3 \%$, with a positive association for the consumption of alcohol $(p<0.05)$.

Table 1 - Sociodemographic characteristics and association with the suspicion of common mental disorders in the sample, Rio de Janeiro, Brazil, 2016

\begin{tabular}{|c|c|c|c|c|c|}
\hline \multirow[t]{2}{*}{ Variable } & \multicolumn{2}{|c|}{$\begin{array}{l}\text { Sociodemographic } \\
\text { characteristics }\end{array}$} & \multicolumn{2}{|c|}{$\begin{array}{l}\text { Suspicion of } \\
\text { CMD }\end{array}$} & \multirow[t]{2}{*}{$p$ value } \\
\hline & $\mathbf{n}$ & $\%$ & $\mathbf{n}$ & $\%$ & \\
\hline Gender & & & & & $0.151^{*}$ \\
\hline Female & 77 & 90.6 & 44 & 93.6 & \\
\hline Male & 08 & 9.4 & 03 & 6.4 & \\
\hline Age group & & & & & $0.500 * *$ \\
\hline 20 to 25 & 75 & 88.2 & 42 & 89.3 & \\
\hline$>25$ & 10 & 8.5 & 05 & 6.4 & \\
\hline Marital status & & & & & $0.262^{*}$ \\
\hline Single & 79 & 93 & 44 & 93.6 & \\
\hline $\begin{array}{l}\text { Married/common-law } \\
\text { marriage }\end{array}$ & 06 & 7.0 & 03 & 6.4 & \\
\hline Live with parents & & & & & $0.271^{*}$ \\
\hline Yes & 61 & 71.7 & 37 & 78.7 & \\
\hline No & 24 & 29.3 & 10 & 21.3 & \\
\hline Employment relationship & & & & & $0.271 *$ \\
\hline Yes & 10 & 11.8 & 37 & 78.7 & \\
\hline No & 75 & 88.2 & 10 & 21.3 & \\
\hline $\begin{array}{l}\text { Medical leave in the last } \\
12 \text { months }\end{array}$ & & & & & $0.213^{*}$ \\
\hline Yes & 13 & 15.3 & 9 & 19.4 & \\
\hline No & 72 & 84.7 & 38 & 80.6 & \\
\hline Use of medicines & & & & & $0.299^{*}$ \\
\hline Yes & 37 & 43.5 & 20 & 42.5 & \\
\hline No & 48 & 56.5 & 27 & 57.5 & \\
\hline $\begin{array}{l}\text { Practice of physical } \\
\text { activity }\end{array}$ & & & & & $0.085^{*}$ \\
\hline Yes & 33 & 38.8 & 16 & 34 & \\
\hline No & 52 & 61.2 & 31 & 66 & \\
\hline Sleep hours & & & & & $0.627^{* *}$ \\
\hline$<8 \mathrm{~h}$ & 82 & 96.5 & 45 & 95.7 & \\
\hline$>8 h$ & 3 & 3.5 & 2 & 4.3 & \\
\hline Alcohol consumption & & & & & $0.041^{*}$ \\
\hline Yes & 39 & 45.9 & 28 & 59.5 & \\
\hline No & 46 & 54.1 & 19 & 40.5 & \\
\hline Tobacco use & & & & & $0.366^{*}$ \\
\hline Yes & 1 & 1.12 & 1 & 1.2 & \\
\hline No & 84 & 98.8 & 46 & 100 & \\
\hline
\end{tabular}

Note: *Chi-Square-Pearson test; **Fisher's exact test; CMD-common mental disorders.

\section{Predictive signs and symptoms of common mental disor- ders in the sample}

Table 2 presents an overview of the answers to the SQR-20 questions, in order to check the most prevalent signs and symptoms of CMD in the sample.

In the statistical analysis of the prevalent factors of CMD suspicion, the following affirmative answers were found: factor 1 - prevalence of answers for the questions "feel nervous, tense or worried" and "feeling sad lately". Factor II - prevalence for "difficulty making decisions", "getting tired easily" and "feeling tired all the time". Factor III - prevalence for "sleeping poorly", "feeling discomfort in the stomach" and "frequent headaches". Factor IV - Prevalence to "lose interest in things" and "feel unable to play a useful role in your life". The positive answer for "have had an idea of ending your life", pointed out. As the data were collected 
Table 2 - Answers to the Self-Report Questionnaire (n=85), Rio de Janeiro, Brazil, 2016

\begin{tabular}{|c|c|c|c|c|}
\hline \multirow{2}{*}{ SQR-20 Factors } & \multicolumn{2}{|c|}{ Yes } & \multicolumn{2}{|c|}{ No } \\
\hline & $\mathbf{n}$ & $\%$ & $\mathbf{n}$ & $\%$ \\
\hline \multicolumn{5}{|l|}{ Factor 1 - Anxious depressive mood } \\
\hline Do you feel nervous, tense, or worried? & 81 & 95.3 & 4 & 4.7 \\
\hline Are you scared easily? & 42 & 49.4 & 43 & 50.6 \\
\hline Are you feeling sad lately? & 46 & 54.1 & 39 & 45.9 \\
\hline Do you cry more than usual? & 33 & 38.9 & 52 & 61.1 \\
\hline \multicolumn{5}{|l|}{ Factor II - Decrease in vital energy } \\
\hline Do you feel tired easily? & 56 & 65.9 & 29 & 34.1 \\
\hline Do you have difficulty making decisions? & 62 & 72.9 & 23 & 27.1 \\
\hline Do you have difficulty being satisfied with your tasks? & 37 & 43.5 & 48 & 56.5 \\
\hline Do you have difficulty thinking clearly? & 44 & 51.8 & 41 & 48.2 \\
\hline Does your work cause you suffering? & 15 & 17.6 & 70 & 82.4 \\
\hline Feeling tired all the time & 55 & 64.8 & 30 & 35.2 \\
\hline \multicolumn{5}{|l|}{ Factor III - Somatic Symptoms } \\
\hline Do you have stomach discomfort? & 39 & 45.8 & 46 & 54.2 \\
\hline Do you have lack of appetite? & 13 & 15.3 & 72 & 84.7 \\
\hline Do you have headache often? & 35 & 41.2 & 50 & 58.8 \\
\hline Do you sleep badly? & 51 & 60.0 & 34 & 40.0 \\
\hline Do you have poor digestion? & 28 & 32.9 & 57 & 67.1 \\
\hline Do you have hand tremors? & 13 & 15.2 & 72 & 84.8 \\
\hline \multicolumn{5}{|l|}{ Factor IV - Depressive thoughts } \\
\hline Have you lost interest on things? & 32 & 37.6 & 53 & 62.4 \\
\hline Are you unable to play a useful role in your life? & 15 & 17.6 & 70 & 82.4 \\
\hline Do you feel worthless in your life? & 8 & 9.4 & 77 & 90.6 \\
\hline Have you had an idea of ending your life? & 1 & 1.2 & 84 & 98.8 \\
\hline
\end{tabular}

consumption of alcohol and other drugs, as a coping and/or socialization strategy ${ }^{(16)}$.

Students are vulnerable to occupational stressors due to inexperience and because it is a young group, factors that may favor $\mathrm{CMD}$ according to the demands of health work. In this type of exposure, there are twice as many chances of the individual suffering from this disorder as compared to those not exposed ${ }^{(8)}$. In addition, there is an incipience of studies on CMD in Nursing and students, which points out the need to verify this disorder with a view to the prevention of mental health problems and the referral for specific mental health care(9).

Although the logistic regression analysis did not associate CMD with the female sex and the age group, attention should be paid to these variables and their influence on the onset of the disorder. Students of the biology, physiotherapy and psychology courses, whose sociodemographic characteristics are close to the study, have higher predisposition to CMD in the first year, but Physiotherapy and Nursing are the careers where the prevalence is $25 \%$ in comparison with the other areas. Another variable to be considered is the risk of suicide among students when analyzing the prevalence of depressive symptoms, and among them, the positive answer for the question "have had an idea of ending your life" ${ }^{\prime \prime(17)}$.

A study involving nursing, medical and odontology

in groups of a maximum of eight students, at the end the instruments were checked for completeness, and it was offered mental health support to those with a suspicion of CMD.

\section{DISCUSSION}

As identified in the study, there was a prevalence of young, female and single participants and who live with their parents. These data are in agreement with other findings in the literature that point to the positive association of CMD in young, single and female individuals ${ }^{(12)}$. To live with parents can be a protective factor of CMD, because the family is an important network of psychosocial support in affective and material terms. The prevalence of female sex is characteristic of Nursing and the nature of work, although there is an increase in the number of men entering the profession ${ }^{(13)}$.

The suspicion of CMD in $55.3 \%$ of the sample is a concern because it is well over national studies and also in Nursing ${ }^{(14)}$. In a survey conducted with students from the last periods of the undergraduate nursing course, the prevalence of $C M D$ was $33.7 \%$, in which $46.1 \%$ said they "felt nervous, tense or worried" and $28.9 \%$ "feeling sad lately"(4).

Considering the association of alcohol consumption and the suspicion of CMD in the sample, confirms the importance of strategies to prevent consumption in the group and support in mental health, considering the burden of problems of this nature that may influence the attitudes in relation to care for one's own health and implications for training ${ }^{(15)}$. The professionalizing cycle is a moment of transition marked by the conviviality of the undergraduate with the cycle of life and death, the demands of training and the concern with the insertion in the job market. These factors make students vulnerable to problems of mental health and the students from the last three semesters identified the suspicion of $\mathrm{CMD}$ in $33.7 \%$ of the sample and the association with the following variables: female sex, the fact that the course is not a source of pleasure and the student that was emotionally tense. The likelihood of developing CMD in the group was higher among students who did not have emotional support, those who were unhappy, and those who did not have positive expectations about the future ${ }^{(14)}$.

Canadian research on psychic suffering in nursing students has shown symptomatology of stress and anxiety associated with clinical practice, the resulting imbalance between the demands of training and personal life, and the use of ineffective coping strategies. It was suggested the planning of the curriculum in order to provide free time for leisure, coexistence with peers and family; and self-care. Students' expectations for pre-university training and access to mental health services should be worked out ${ }^{(18)}$.

Regarding the predictive signs and symptoms of CMD in the sample, it was evidenced the prevalence of anxious depressive mood in the question of "feeling nervous, tense or worried" and "feeling sad lately". Among the residents of the health area (Nursing, Nutrition, Medicine and Collective Health), the most frequent complaints were: "feeling nervous, tense or worried", "sleeping poorly" and "getting tired easily". Among women, $73.8 \%$ stated "feeling nervous, tense or worried" and $76.8 \%$ of men said "sleeping poorly". "getting tired easily" and "having unpleasant sensations in the stomach" were the complaints most often reported by women compared to men ${ }^{(9)}$.

In relation to the decrease in vital energy, the participants affirmed "difficulty in making decisions", "getting tired easily" and "feeling tired all the time"; Similar results were found in a study with nursing students in which $32.9 \%$ of the participants stated "difficulty in making decisions" and 26.3\% "getting tired easily"(4). Decreased in vital energy may be in line with the requirements 
of training in the professional cycle in view of the few hours of sleep, travel to the fields of practice, the monograph and the wearing resulting from activities in the practice fields $s^{(3)}$.

Findings about somatic symptoms revealed problems with sleep, discomfort in the stomach and frequent headaches. These data are similar to the study with nursing students, in which $31.6 \%$ had positive answers to "frequent headaches" and $25 \%$ to "unpleasant sensations in the stomach"(4). Poor sleep quality was a factor associated with the 3.3 times higher chance of CMD in medical students from the first and last semesters, compared to those with good sleep quality ${ }^{(19)}$.

Poor sleep pattern and headache are symptoms that negatively influence the attention required in care and contribute to incidents that compromise patient and worker safety. These aspects have been little valued in the assessments of adverse events that occur in Nursing, whose activities, despite providing opportunities for learning, decision making and autonomy, have been pointed as sources of tension and wearing ${ }^{(7)}$.

About depressive symptoms, there was prevalence for the questions "lose interest in things" and "feel unable to play a useful role in your life". A study on the suspicion of depression in medical students ( $n=384$ ), using the Beck Depression Inventory $(\mathrm{BDI})$, showed signs indicating depression and somatic reactions accompanied by anxiety, difficulty to sleep and chronic diseases. Such disturbances were associated with years of schooling, restraint of leisure time and relaxation with colleagues, and the fact that the students take care of patients with many diseases ${ }^{(20)}$.

Neurotransmitter changes, personality features, genetic vulnerability and situational events are factors intrinsic to the individual and when associated with external factors can trigger depressive reactions. In Nursing, external factors may be related to the physical and social environment of work, such as: practice sectors, shift -especially at night-, conflicting interpersonal relationships, work overload, lack of autonomy, conflict of interests, care provided to patients at risks of complication and death, poor social support; and ineffective coping strategies in the management of situations considered as anxiogenic ${ }^{(21)}$.

Depression reaches larger-scale younger groups in Nursing compared to older ones whose cognitive and emotional maturity bring safety for problem solving and adversity coping. The youth's vulnerability would be linked to the lack of experience in dealing with everyday work situations such as: insecurity, lack of autonomy, work overload and difficult interpersonal relationships. Such factors are important for changes in mental health and depressive disorder production, with a positive correlation for the risk of suicide among those with low self-esteem and absence of professional achievement ${ }^{(17)}$.

\section{Study limitations}

The results presented should be analyzed based on some methodological limitations, since this is a cross-sectional study that evaluates only association between the variables, without defining or establishing causal link. The sample, although representative of the universe of students in the professionalizing cycle, was restricted to a single higher education institution, which may have contributed to the high prevalence of students with a suspicion of CMD and the association with alcohol consumption alone. Such limitations may foster interest in other studies of this nature so that one can not only estimate the prevalence of CMD suspicion, but also the relation with variables of the participants and their influence on the students' mental health. The incipience of CMD studies in nursing students was another limiting factor in terms of comparison and discussion of the findings.

\section{Contributions to the Nursing}

The high percentage of suspicion of CMD in students of the professionalizing cycle in the study should be discussed and analyzed by professors and institutions due to the risk of developing severe mental disorders, with negative repercussions for the training, care process and personal and social quality of life. There is a need for preventive and therapeutic actions with undergraduates in order to minimize psychic suffering, prevent alcohol consumption and other drugs use, and improve the quality of life to face challenges imposed by the professionalizing cycle. Such actions may also contribute to patient safety under the care of students.

\section{CONCLUSION}

The high percentage of suspicion of CMD in nursing students in the professionalizing cycle, whose sample consisted mainly of young, single and female people, is well over the prevalence found in other studies with nursing students and other health professionals. Although it was proved the association of CMDs with the consumption of alcohol in the sample, it is not ruled out that other variables may influence the suspicion of this disorder in the group such as the few hours of sleep, the use of medications and the removal of the training environment for the treatment of health problems.

Considering the specificity of the act of caring for the human being in their different life cycles, Nursing and training institutions should join efforts in order to promote preventive and therapeutic actions among students that minimize the possibility of severe mental disorders and consumption of alcohol and other drugs.

\section{REFERENCES}

1. Pandovani RC, Neufeld CB, Maltoni J, Barbosa LNF, Souza WF, Cavalcanti HAF, et al. Vulnerabilidade e bem-estar psicológicos do estudante universitário. Rev Bras Ter Cogn. 2014;10(1):2-10. doi: 10.5935/1808-5687.20140002

2. Garcia SD, Ignotti BS, Ciciliato CZ, Vannuchi MTO. The meaning of nursing internship to inters at a public university. Rev Enferm UERJ [Internet]. 2015 [cited 2018 Jan 2];22(2):212-8. Available from: https://www.e-publicacoes.uerj.br/index.php/enfermagemuerj/article/view/13601

3. Oliveira EB, Costa SLT, Guimarães NSL. O trabalho do acadêmico de enfermagem no hospital geral: riscos psicossociais. Rev Enferm UERJ [Internet]. 2012 [cited 2018 Jan 03];20(3):317-22. Available from: https://www.e-publicacoes.uerj.br/index.php/enfermagemuerj/article/view/2950 
4. Silva BP, Corradi-Webster CM, Gherardi-Donato ECS, Hayashida M, Siqueira MM. Common mental disorders, alcohol consumption and tobacco use, among nursing students at a public university in the western Brazilian Amazon. Smad, Rev Eletrônica Saúde Mental Álcool Drog. 2014;10(2):93-100. doi: 10.11606/issn.1806-6976.v10i2p93-100

5. World Health Organization (WHO). A user's guide to the Self Reporting Questionnaire (SRQ) [Internet]. Geneva; 1994 . [cited 2018 Jan 7]. Available from: http://apps.who.int/iris/bitstream/10665/61113/1/WHO_MNH_PSF_94.8.pdf

6. Jansen K, Mondin TC, Ores LC, Souza LDM, Konradt CE, Pinheiro RT, et al. Transtornos mentais comuns e qualidade de vida em jovens: uma amostra populacional de Pelotas, Rio Grande do Sul, Brasil. Cad Saúde Pública. 2011;27(3):440-8. doi: 10.1590/S0102-311X2011000300005

7. Urbaneto JS, Magalhães MCC, Maciel VO, Sant'Anna VM, Gustavo AS, Poli-de-Figueiredo CE, et al. Work-related stress according to the demand-control model and minor psychic disorders in nursing workers. Rev Esc Enferm USP. 2013;47(3):1180-6. doi: 10.1590/ S0080-623420130000500024

8. Carvalho CN, Melo-Filho DA, Carvalho JAG, Amorim ACG. Prevalência e fatores associados aos transtornos mentais comuns em residentes médicos e da área multiprofissional. J Bras Psiquatr. 2013;62(1):38-45. doi: 10.1590/S0047-20852013000100006

9. Alves AP, Pedrosa LAK, Coimbra MAR, Miranzi MAS, Hass VJ. Prevalence of common mental disorders among health professionals. Rev Enferm UERJ. 2015;23(1):64-9. doi: 10.12957/reuerj.2015.8150

10. Mari JJ, Williams P. A validity study of a psychiatric screening questionnaire (SRQ-20) in primary care in the city of São Paulo. Br J Psychiatry. 1986;148:23-6.

11. Gonçalves DM, Stein AT, Kapczinski F. Avaliação de desempenho do Self-Reporting Questionnaire como instrumento de rastreamento psiquiátrico: um estudo comparativo com o Structured Clinical Interview for DSM-IV-TR. Cad Saúde Pública. 2008;24(2):380-90. doi: 10.1590/ S0102-311X2008000200017

12. Bublitz S, Guido LA, Kirchhof RS, Neves ET, Lopes LFD. Sociodemographic and academic profile of nursing students from four Brazilian institutions. Rev Gaúcha Enferm. 2015;36(1):77-83. doi: 10.1590/1983-1447.2015.01.48836

13. Machado MH, Aguiar Filho W, Lacerda WF, Oliveira $E$, Lemos W, Wermelinger M, et al. Características gerais da enfermagem: o perfil sócio demográfico. Enferm Foco. 2015;6(1/4):11-7. doi: 10.21675/2357-707X.2016.v7.nESP.686

14. Costa EFO, Rocha MMV, Santos ATRA, Melo EV, Martins LAN, Andrade TM. Common mental disorders and associated factors among finalyear healthcare students. Rev Assoc Med Bras. 2014; 60(6):525-30. doi: 10.1590/1806-9282.60.06.009

15. Crawford G, Burns SK, Chih HJ, Hunt K, Tilley PJM, Hallett J, et al. Mental health first aid training for nursing students: a protocol for a pragmatic randomised controlled trial in a large university. BMC Psychiatry. 2015;15:26. doi: 10.1186/s12888-015-0403-3.

16. Espiridião E, Barbosa JA, Silva NS, Munari DB. The mental health of nursing student: an integrative review of literature. Smad, Rev Eletrônica Saúde Mental Álcool Drog. 2013;9(3):144-53. doi: 10.11606/issn.1806-6976.v9i3p144-153

17. Silva DSD, Tavares NVS, Alexandre ARG, Freitas DA, Brêda MZ, Albuquerque MCS et al. Depression and risk of suicide in professional nursing: integrative review Rev Esc Enferm USP. 2015;49(6):1023-31. doi: 10.1590/S0080-623420150000600020

18. Chernomas WM, Shapiro C. Stress, depression, and anxiety among undergraduate nursing students. Int J Nurs Educ Scholarsh. 2013;10. doi: 10.1515/ijnes-2012-0032.

19. Ferreira CMG, Kluthcovsky ACGC, Cordeiro TMG. Prevalence of common mental disorders and associated factors among medical students: a comparative study. Rev Bras Educ Med. 2016;40(1):268-77. doi: 10.1590/1981-52712015v40n2e02812014

20. Baldassin S, Silva N, Alves TCTF, Castaldelli-Maia JM, Bhugra D, Nogueira-Martins MCF. Depression in medical students: cluster symptoms and management. J Affect Disord. 2012;150(1):110-4. doi: 10.1016/j.jad.2012.11.050

21. Martins JT, Ribeiro RP, Remijo KP, Ribeiro PHV. Mental disorders linked to the nursing work: integrative review. Rev Enferm UFPE. 2014;8(6):1746-56. doi: 10.5205/1981-8963-v8i6a13650p1746-1756-2014 